\title{
Gene Therapy in Urology
}

\author{
Ratha Mahendran, Sin Mun Tham and Kesavan Esuvaranathan \\ Department of Surgery, Yong Loo Lin School of Medicine, \\ National University of Singapore \\ Singapore
}

\section{Introduction}

The application of gene therapy in the field of Urology is not limited to cancer therapy but is also being evaluated for non-cancer related bladder dysfunctions as well as erectile dysfunction (ED). This article will review the use of gene therapy for these conditions; the vectors used and limitations associated with different gene delivery systems and the attempts to overcome these shortcomings.

\section{Bladder cancer}

Bladder cancer is the $7^{\text {th }}$ most common cancer worldwide. It has a natural history of superficial recurrences and local progression. It is estimated that within 18 months of first diagnosis approximately $50 \%$ of patients will have a recurrence (Anderson \& Naish 2008). Thus there is a need for frequent monitoring of these patients. In the US the estimated lifetime cost of therapy for bladder cancer patients with non-muscle invasive disease was US $\$ 21.03$ million based on a Medicare database (Cooksley et al. 2008). The majority of this is spent on surveillance and the treatment of recurrences. Tumors occur on the luminal surface of the bladder and the architecture of the bladder permits topical intravesical therapies. The bladder is isolated from other organs and tissues and intravesical therapy permits contact with the entire internal surface of the bladder with minimal systemic side-effects.

The present gold standard therapy for superficial bladder cancers is immunotherapy with Mycobacterium bovis, Bacillus Calmette Guerin (BCG) following local transurethral resection of the bladder tumor (TURBT). BCG induces a mononuclear and neutrophilic infiltrate in the bladder wall which results in an inflammatory response as measured by cytokine production that causes sloughing of both tumor and normal cells (Herr and Morales 2008). The presence of IL-2, IL-8 and IL-18 in the urine of patients has been reported to correlate with response to therapy (Thalmann et al. 1997; Thalmann et al. 2000; Saint et al. 2003). Unfortunately, BCG has several shortcomings: it is a live vaccine and commonly causes side effects and occasionally septicemia. In addition some patients (20$42 \%$ ) do not respond to therapy (Kamat and Lamm 2000). In place of BCG, recombinant cytokines such as IFN- $\gamma$, TNF- $\alpha$, and IL-2 have been used in a number of clinical trials with encouraging results (Glazier et al. 1995; Den Otter et al. 1998; Stavropoulos et al. 2002). However, recombinant cytokines are costly, unstable in urine and have poor permeability 
across the glycosaminoglycan (GAG) layer of the urothelium. Gene therapy is a natural alternative approach to ensure cytokine production in the bladder environment.

\subsection{Viral transfection systems for bladder cancer}

Initially replication defective viruses were generated with the sole purpose of gene delivery (Thomas et al. 2003). The viruses evaluated included: Adenovirus (type 2 and 5), Adenoassociated virus (Parvoviridae family), Herpes simplex virus, Retrovirus (Dumey et al. 2005), Canary pox virus and Vaccinia virus (Lee et al. 1994). Table 1 lists their characteristics.

However, because of the limited transduction capability of some viruses, replicating and conditionally replicating viruses were developed. These viruses amplify the transfection efficiency, as virus transduced cells produce more viruses that can infect the surrounding cells. Replication of wild type viruses also induces cytolysis of infected cells.

\subsubsection{Limitations and Improvements}

\subsubsection{Non-specificity of transfection}

Siemens et al. compared adeno-, canary pox and vaccinia viruses in terms of their ability to transfect tumor cells after intravesical delivery in a murine model of bladder cancer (Siemens et al. 2003). The vaccinia and avian pox viruses were better at transfecting tumor cells than adenoviruses but all three resulted in transfection of extravesical tissue (e.g. kidney, liver, spleen). In contrast Wood et al reported only sporadic extravesical transfection after intravesical adenovirus instillations (Wood et al. 1999).

To reduce non specific viral transduced gene expression, oncolytic adenoviruses have been engineered to express the E1A and E1B genes under the control of the uroplankin II gene promoter (Zhang et al. 2002; He et al. 2009) which limits expression to urothelial cells. Another strategy to target viral replication to tumor cells is to place the adenovirus E1A gene under the control of the telomerase promoter (Lanson et al. 2003), the midkine gene promoter (Terao et al. 2007) or the Cox-2 promoter (Shirakawa et al. 2004). All these genes are highly expressed in tumor cells.

Bladder cancer cells often over-express the epidermal growth factor receptor (EGFR) and targeting EGFR with bi-specific antibodies improved the delivery of adenovirus to cancer cells (van der Poel et al. 2002). A gammaretrovirus carrying a chimeric envelope protein containing a single chain variable fragment $(\mathrm{scFv})$ antibody to the human epidermal growth factor receptor 2 (HER2) was shown to specifically target cells expressing Her2 (Tsai et al. 2010).

\subsubsection{Transfection efficiency}

The internal surface of the bladder is covered by uroplakin proteins and the GAG layer which together provide a barrier to transfection of urothelial cells. Agents that disrupt this protective layer such as ethanol, $\mathrm{HCl}$, dodecyl-B-d-maltoside and sodium dodecyl sulphate have been shown to improve viral transduction of the bladder (Engler et al. 1999; Lin et al. 2002; Ramesh et al. 2004).

Though adenoviruses are the most popular viruses for gene therapy they require adhesion with the cellular coxsackie-adenoviral receptor (CAR) for transduction of mammalian cells. Neoplastic tissue unlike normal bladder cells have reduced CAR expression (Buscarini et al. 2007) as a result of epigenetic control mechanisms (Pong et al. 2003). 


\begin{tabular}{|c|c|c|c|c|}
\hline Virus & $\begin{array}{c}\text { Transfection } \\
\text { efficiency }\end{array}$ & Immunogenicity & $\begin{array}{c}\text { DNA } \\
\text { inserts }\end{array}$ & Gene expression \\
\hline Adenovirus & $\begin{array}{c}\text { High with } \\
\text { CAR receptor }\end{array}$ & high & $8 \mathrm{~kb}$ & $\begin{array}{c}\text { Transient expression, DNA } \\
\text { remains episomal }\end{array}$ \\
\hline $\begin{array}{c}\text { Adeno-associated } \\
\text { virus }\end{array}$ & $\begin{array}{c}\text { Good, no } \\
\text { receptor }\end{array}$ & low & $4.5 \mathrm{~kb}$ & Stable, DNA episomes found \\
\hline $\begin{array}{c}\text { Herpes simplex } \\
\text { virus }\end{array}$ & $\begin{array}{c}\text { High in } \\
\text { neurons }\end{array}$ & high & $>30 \mathrm{~kb}$ & $\begin{array}{c}\text { Stable in neurons and transient } \\
\text { in others, episomal }\end{array}$ \\
\hline $\begin{array}{c}\text { Moloney murine } \\
\text { leukemia virus }\end{array}$ & $\begin{array}{c}\text { High in } \\
\text { dividing cells }\end{array}$ & low & $8 \mathrm{~kb}$ & $\begin{array}{c}\text { Stable expression, DNA } \\
\text { integration into host genome } \\
\text { Hematopoietic cells }\end{array}$ \\
\hline Lentivirus & $\begin{array}{c}\text { Non dividing } \\
\text { cells }\end{array}$ & low & $8 \mathrm{~kb}$ & $\begin{array}{c}\text { Stable expression, Integration } \\
\text { in host chromosome, }\end{array}$ \\
\hline Canary pox virus & Most cells & low & $25 \mathrm{~kb}$ & $\begin{array}{c}\text { Transient expression, Viral } \\
\text { DNA limited to cytoplasm }\end{array}$ \\
\hline Vaccinia virus & Most cells & high & $\begin{array}{c}\text { Up to } \\
25 \mathrm{~kb}\end{array}$ & $\begin{array}{c}\text { Transient expression, Viral } \\
\text { DNA limited to cytoplasm }\end{array}$ \\
\hline
\end{tabular}

Table 1. Characteristics of viral vectors for gene therapy

To circumvent the need for receptor mediated uptake, polymers have been used to enhance adenovirus transfection of bladder cells (Kasman et al. 2009) or even small molecule excipients such as Syn3 (Connor et al. 2001; Yamashita et al. 2002; Nagabhushan et al. 2007). A recent study has shown that CAR receptor expression and thus adenoviral expression can be increased by treatment with histone deacetylase inhibitors (HDACI) such as trichostatin A and sodium phenylbutyrate (Sachs et al. 2004).

\subsubsection{Previous Immunity}

Vaccinia viruses have long been used in man as vaccines against smallpox. This raised the issue of whether previous immunization would block the effectiveness of these viruses as gene delivery vehicles. Intravesical instillation of vaccinia viruses was successfully demonstrated in pre-immunized mice (Lee et al. 1994). The immunogenicity of adenoviruses is a major limitation in most therapeutic strategies. However it may be advantageous in bladder cancer therapy where non-specific inflammation as a consequence of BCG instillation has been associated with tumor removal.

\subsubsection{Promoter inactivation}

Adenovirus genes expressed from a CMV promoter induced better gene expression than those expressed using a RSV promoter (Freund et al. 2000). But quite often the CMV promoter is inactivated in vivo. It has been found that adenoviral transfection together with HDAC inhibitor trichostatin or retinoic acid improved CMV promoter activity. Treatment with these drugs could improve and prolong adenoviral transgene expression (Gaetano et al 2000). The development of tissue specific promoters as described above may resolve this problem.

\subsection{Non-viral transfection systems for bladder cancer}

The strength and weakness of non-viral vectors is the transient expression of the delivered genes. For non-viral gene delivery the genes are encoded on plasmid DNA of bacterial 
origin. Non-viral delivery agents include liposomes (N-[1-(2,3-Dioleoyloxy)propyl]-N,N,Ntrimethylammonium chloride, DOTAP), polyethylenimine (PEI), viral envelopes (with fusogenic properties) conjugated to liposomes (Hemagglutinating Virus of Japan (HVJ) liposomes), chitosans as well as physical means such as the use of an electrogun or ultrasound (Harimoto et al. 1998; Lawrencia et al. 2001; Ogawa et al. 2004; Bonnet et al. 2008; Tsai et al. 2009; Zaharoff et al. 2009). Plasmid DNA delivery systems result in cellular entry via the endosomes (Al-Dosari \& Gao 2009). Endosomal escape is often difficult and when successful the plasmid DNA is mainly restricted to the cytoplasm. A small amount may make it to the nucleus and exist as episomal DNA molecules that can be lost during replication (Al-Dosari \& Gao 2009). Besides the delivery agents, the plasmid DNA sequence can also modulate the efficiency of transfection as discussed below.

\subsubsection{Limitations and Improvements}

\subsubsection{Promoter inactivation}

It has been reported that the CMV promoter often used for plasmid gene expression does not always result in good gene expression (Loser et al. 1998) as a consequence of promoter inactivation. This can be overcome by using a HDAC inhibitor, as demonstrated with OSUHDAC42 (Lai et al. 2010). An alternative strategy is to utilize tissue/cancer cell specific promoters such as the COX-2, H19 and human IGF2-P4 gene promoters (Ohana et al. 2002; Zhang et al. 2008; Amit \& Hochberg 2010).

\subsubsection{Transfection efficiency}

The primary focus of improving plasmid DNA transfection is improving escape from the endosomes and this is achieved by developing new additives and lipoplexes or even polyplexes that use either acidification or osmotic pressure changes or membrane fusogenic molecules to allow DNA escape (Al-Dosari and Gao 2009). We developed a formulation comprised of DOTAP and Methyl- $\beta$-cyclodextrin solubilized cholesterol (MBC) that transfects urothelial cells in vivo within 2 hours of exposure. Transfection was confined to the bladder (Lawrencia et al. 2001) and occurred in the superficial and deeper layers of the urothelial tumours (Wu et al. 2003).

\subsubsection{Specificity of plasmid expression and activity/duration}

Antibodies have been used to target delivery of plasmids to tumor cells. ScFv antibody to Her-2 (Tsai et al. 2009) or transferrin have been demonstrated to successfully target plasmids to tumor cells (Pirollo et al. 2008). The latter strategy targets both primary and metastatic disease when delivered systemically. Targeting of plasmid DNA to the nucleus can also be induced by introducing mammalian transcription factor binding sites in the plasmid and this increased the duration of expression (Gill et al. 2009).

Plasmid DNA expression is transient because of the episomal nature of transfected DNA. In bladder cancer therapy this can be overcome by repeated intravesical instillations. Another strategy to improve gene expression is to add a scaffold matrix attachment region (S/MAR) to the plasmid DNA. S/MAR serve both to ensure prolonged gene expression, by reducing the silencing of plasmid DNA as well as to ensure plasmid DNA replication as episomes (Gill et al. 2009).

Integration of plasmid DNA into chromosomal DNA is achievable now. The techniques used include retroviral integrase (Tanaka et al. 1998), sleeping beauty (SB) transposons 
(Hackett et al. 2010) or phage recombinase mediated integration (Olivares et al. 2002). Thus in the future a single intravesical instillation may be sufficient for prolonged therapeutic effects.

\subsubsection{Liposome free delivery}

For small molecules such as CpG oligodeoxynucleotides (ODN), intravesical delivery to urothelial cells can be achieved without a transfection agent (Ninalga et al. 2005). But plasmid DNA requires a delivery agent. Nanoparticles $(10-100 \mathrm{~nm}$ in size) with bound plasmid DNA are recognized by cell surface nucleolin on HeLa cells and this results in DNA transport to the nucleus (Chen et al. 2008) and avoidance of endosomal entrapment.

\subsubsection{Inflammation}

The CpG sequences on plasmid DNA induce inflammation that could reduce gene expression by either destruction of transfected cells or promoter inactivation (Yew et al. 2000). Minicircle DNA (mcDNA), are supercoiled DNA with only the therapeutic gene cassette. They are generated in vivo by site specific recombination in E coli and exhibit improved gene expression in terms of the level and duration of gene expression (Darquet et al. 1997).

\subsection{Preclinical evaluation of genes and evolving gene therapy strategies}

The different categories of genes used successfully in animal studies are listed in Table 2 . Both Sub-cutaneous (sc) and orthotopic models of bladder cancer have been used to evaluate gene therapy. While the data from sc studies have shown the efficacy of the expressed genes, it is the orthotopic models that best reflect clinical disease and therapeutic gene delivery. In general regardless of the delivery system or gene delivered tumor growth reduction or even eradication has been reported in murine models of bladder cancer. Most therapeutic schedules used in the animal studies require repeated instillations of the gene delivery vehicle whether it is a viral or non-viral vector. However, a recent study of viral gene delivery of IFN $\alpha$ indicated that a high dose could reduce the need for increased intravesical instillations (Tao et al. 2006). Transfection using transposons may also reduce the need for repeated transfection of plasmid DNA.

New therapies aim to combine several strategies at once. These include the use of oncolytic viruses and immune modulation using GMCSF (Cozzi et al. 2001; Ramesh et al. 2006); wild type p53 and ribozyme erb-2 (Irie et al. 2006) and Rb94 or oncolytic viruses and chemotherapeutic drugs (Zhang et al. 2002; Pirollo et al. 2008). In vitro studies have shown that combining AdHSVTK, ganciclovir and chemotherapy may have therapeutic benefit (Freund et al. 2003). Further the beneficial effect of 5-FU and adenovirus cytosine deaminase gene therapy could be enhanced by irradiation (Zhang et al. 2003). Such multi-factor therapies may be better at eradicating tumor cells. Another strategy is to modify immune cells in vitro for cancer therapy. Dendritic cell manipulation by transfection with adenovirus carrying the survivin gene has been shown to induce cytotoxic T lymphocytes ( CTLs) (Kikkawa et al. 2009).

\subsection{Gene therapy clinical trials}

Table 3 lists several Phase I trials that have been carried out for bladder cancer. However, results from only a few of these trials are published. 


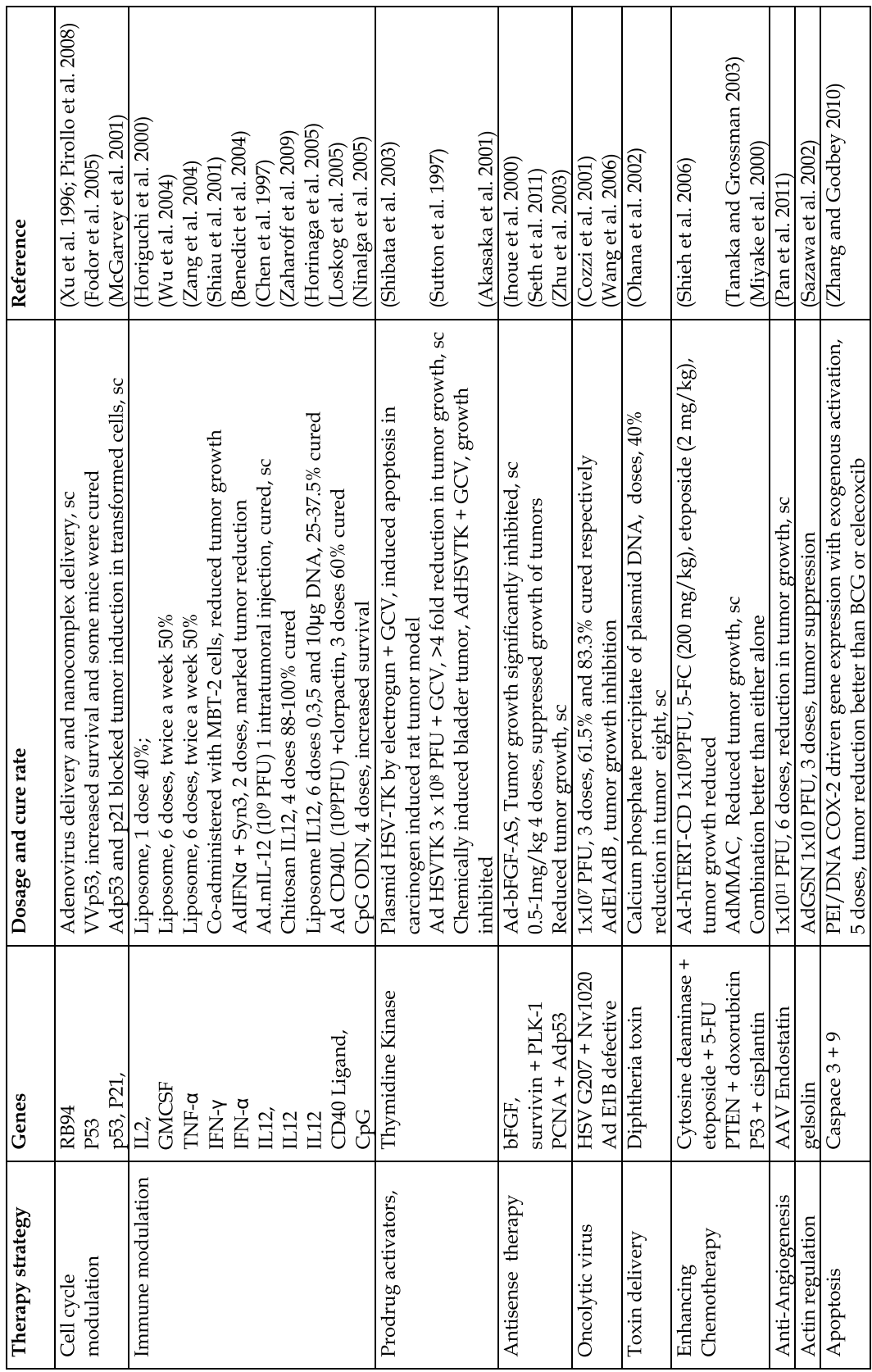

sc -stands for sub-cutaneous models.

Table 2. Genes demonstrated to cause tumor reduction in murine models of bladder cancer. 


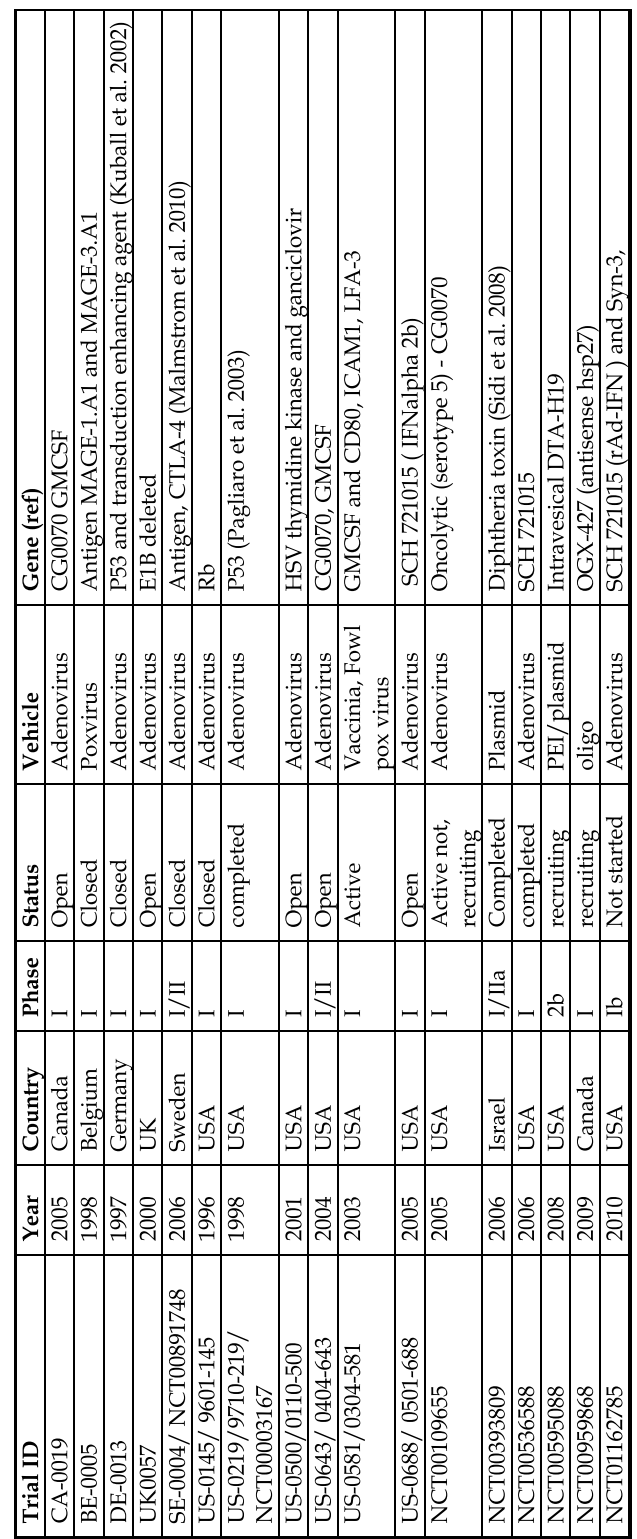

Table 3. Clinical trials for bladder cancer gene therapy. NCT designation indicates data obtained from http://www.who.int/ictrp/en/;

Other alphabet and number designations are for data obtained from http://www.wiley.com/legacy/wileychi/genmed/clinical where the alphabets indicate country of registration and the numbers only designation are for data obtained from http://www.gemcris.od.nih.gov/Contents/GC_HOME.asp . Note some trials were registered on more than one web-site. 
Information about completed, on-going and planned trials were obtained from the following sources: gene therapy clinical trials world wide web-site http:/ /www.wiley.com /legacy/wileychi/genmed/clinical/; the clinical trials.gov, US National Institutes of Health and the Genetic Modification Clinical research Information System database http://www.gemcris.od.nih.gov/Contents/GC_HOME.asp and the World Health Organization International Clinical Trials registry platform portal http://www.who.int /ictrp/en/.

A Phase I trial on vaccinia virus instillation showed increased lymphocyte recruitment and the induction of an inflammatory response in the bladder (Gomella et al. 2001). There were no clinical manifestations of vaccinia toxicity indicating the safety and therapeutic potential of this virus as a gene therapy vector. Adenovirus delivery of p53 was also shown to successfully deliver p53 gene to bladder cells but there was no change in immunohistochemical detection of p53 in bladder tissue (Pagliaro et al. 2003). However, adenovirus therapy was safe and well tolerated (Pagliaro et al. 2003). Delivery of adenovirus carrying p53 with a transduction enhancing agent improved p53 gene delivery and protein expression was found in patient tissue samples (Kuball et al. 2002). Though higher doses of the virus were administered, no dose toxicity was observed (Kuball et al. 2002). Similarly no serious adverse effects were reported by Malmstrom et al. from a recently concluded Phase I/IIa trial using AdCD40L (Malmstrom et al. 2010). They observed gene transfer in biopsies and the infiltration of T lymphocytes (Malmstrom et al. 2010).

A plasmid was used to deliver the diphtheria toxin gene under the control of the H19 gene regulatory sequence in a Phase I/IIa trial for non-muscle invasive bladder cancer (Sidi et al. 2008). They reported mild toxicity and observed complete and partial response in some patients. Thus based on these Phase I trials, both non viral and viral vectors appear to be well tolerated in man.

Several new trials are either in progress or about to commence. These use non-viral and viral delivery vectors as listed in Table 3. A proposal for a Phase I trial for intravesical therapy in bladder cancer patients using plasmid DNA carrying the IFN- $\alpha$ gene and our liposome based delivery system is being evaluated by the Health Sciences Authority, Singapore.

\subsection{Other urological malignancies}

Though not covered here several clinical trials are on-going, evaluating gene therapy for prostate and renal cancers. In general the vectors and genes used are similar though tissue specific promoters may differ. Information on these trials can be obtained from the web-sites listed above. Unlike bladder cancer however, gene delivery to these tissues is not as simple. Thus tissue specific targeted gene expression has been developed. Another strategy is the use of macrophages transfected ex vivo with a plasmid carrying the E1A/B construct under the control of the hypoxia response element (HRE) as well as a replication competent adenovirus with the E1A under the control of the prostate specific antigen promoter. At the hypoxic tumor site the E1A protein is produced and the adenoviruses released infect tumor cells and cause their lysis (Muthana et al. 2011). Such a strategy prevents virus neutralization in vivo.

\section{Non-cancer related urological problems}

The bladder is made up of a reservoir and an outlet (bladder neck, urethra and urethral sphincter) whose activities are controlled by smooth and striated muscles. There are more 
patients with bladder dysfunctions related to its primary function of urine storage and voiding than cancer. These include: lower urinary tract symptoms (LUTS), interstitial cystitis (IC), overactive bladder (OAB), spinal cord injuries affecting micturition and urinary incontinence (UI). It is estimated that by 2018, some 2.3 billion people worldwide will be affected by at least one LUTS, OAB, UI and LUTS suggestive of bladder obstruction (Irwin et al. 2011). LUTS is an umbrella term that encompasses urine storage (increased frequency, at least one episode of nocturia per night, urgency and UI), voiding and post-micturition symptoms (Abrams et al. 2003). Another urological problem is erectile dysfunction (ED). Both LUTS and ED are increased with aging and in patients with diabetes (Brown et al. 2005). With the worldwide increase in the incidence of diabetes the incidence of these urological problems will increase.

Most current therapies for the above mentioned conditions are palliative rather than therapeutic. Gene therapy however, may provide a way to cure the disease and the recent review by Christ lists some of these strategies (Christ 2011). Most of the bladder related problems seem to be linked to muscle and neuronal defects and because of the latter the most common vectors used for animals studies of bladder dysfunctions are HSV vectors.

\subsection{Urinary incontinence}

Urinary incontinence is a general term used to cover three types of incontinence namely stress, urge and overflow (Chancellor et al. 2001). Stress incontinence occurs when the urinary sphincter muscle is unable to prevent urine leakage following jumping or coughing. This is more common in women than men. Treatment approaches include exercise, surgery and collagen injections into the sphincter muscle. Often multiple injections are required which adds to the cost of treatment and some patients are allergic to bovine collagen. Tissue engineering and $e x$ vivo gene therapy are alternative therapeutic strategies that are being evaluated (Shokeir et al. 2010). Phase I trials of the delivery of autologous myoblasts and fibroblasts from muscle biopsies to female patients with stress incontinence have shown some benefit (Mitterberger et al. 2007). In mice, combining myoblast and gene therapy such as the ex vivo transformation of myoblasts with the VEGF gene resulted in improved volume and function of muscle cells (Delo et al. 2008).

Urge incontinence is characterized by increased urinary urgency and frequency caused by involuntary bladder contractions leading to uncontrollable urine leakage. One study has evaluated intravesical non-viral delivery of a cDNA for the $\mathrm{K}+$ channel and showed that this resulted in increased $\mathrm{K}+$ channels in the smooth muscle of the bladder and amelioration of bladder overactivity (Christ et al. 2001).

Overflow incontinence results from nerve damage such that patients cannot urinate. One common cause is diabetes related neuropathy. Diabetes related cystopathy is often irreversible and restoring bladder functions to diabetic patients is difficult (Sasaki et al. 2002). Animal studies have identified nerve growth factor (NGF) as a good candidate for gene therapy for diabetes induced incontinence (Apfel et al. 1994). HSV delivery of NGF increased NGF in the bladder wall and dorsal root ganglion and improved voiding function in streptozotocin (STZ) induced diabetic rats (Goins et al. 2001; Sasaki et al. 2004).

\subsection{Interstitial cystitis/painful bladder syndrome}

Interstitial cystitis or painful bladder syndrome occurs predominantly in females (Persu et al. 2010). It is believed to result from underlying inflammation in the bladder. It cannot be adequately treated by drugs and prolonged drug therapy can lead to dependency and 
tolerance to drugs that may require dose escalation to remain effective. Thus it is a candidate for gene therapy. Delivery of the preproenkephalin gene by HSV (Yokoyama et al. 2009) has been shown to be beneficial in reducing pain. A HSV vector carrying the ionotropic glycine receptor (GlyR) whose expression was induced by glycine had an analgesic effect (Goss et al. 2011). This vector when inoculated into the bladder wall of an inflammation model of $\mathrm{IC} / \mathrm{PBS}$ in rats was activated by systemic glycine delivery.

\subsection{Overactive bladder}

Overactive bladder $(\mathrm{OAB})$ is defined as "urinary urgency, usually accompanied by frequency and nocturia, with or without urgency urinary incontinence" (Haylen et al. 2010) Detrusor over activity is considered a single marker for OAB. It can occur as a result of spinal injury and could result in a lack of control of micturition. This has been demonstrated in animal models of spinal injury. HSV vector delivery of glutamic acid decarboxylase has shown benefit in a rat model of spinal injury (Miyazato et al. 2009; Miyazato et al. 2010).

\subsection{Erectile dysfunction}

Approximately 150 million men are projected to suffer from ED and the incidence of ED increases with age. Normal erectile function occurs as a result of 3 synergistic events namely: neurological mediated penial arterial inflow increase; cavernosal smooth muscle relaxation and restriction of venous outflow from the penis (Andersson \& Wagner 1995). In ED one or more of these events may be impaired. The penis is an excellent candidate for gene therapy because it is easily accessible, has limited blood flow and a slow cellular turnover (Bivalacqua \& Hellstrom 2001). Though therapy is available for erectile dysfunction there are a significant number of patients who do not respond to available therapy (Yoshimura et al. 2010). The recent review by Harraz et al. provides an excellent overview of gene therapy strategies used in animal models of ED that have been shown to resolve this problem (Harraz et al. 2010). Rather than reproducing that information only recent publications not included in that review are mentioned here. Over expression of the transient receptor potential (TRP) channels 6 (dominant negative) by transfection with a plasmid caused a decrease in calcium levels in the corporal smooth muscle and improved erectile function in diabetic rats (Jung et al. 2010). Using a STZ induced diabetes model to evaluate erectile dysfunction, it was found that implantation of mesenchymal stem cells transfected with VEGF improved erectile function compared to implantation of mesenchymal stem cells alone (Qiu et al. 2011).

\subsection{Clinical trials}

Only two clinical trials are listed on the http://www.gemcris.od.nih.gov/Contents /GC_HOME.asp for urological conditions unrelated to cancer. One is the Phase I trial for $\mathrm{ED}$ and the other is a trial for overactive bladder syndrome. Both trials used plasmid DNA carrying the calcium activated potassium channel (Melman et al. 2007). The results of the Phase I trial for ED indicate the safety of this delivery system.

\section{Major issues and future prospects for gene therapy}

One major issue is the safety of gene therapy in terms of its impact on the environment as well as long term safety in patients. Schenk-Braat et al found that only half of all registered 
clinical trials included viral shedding data (Schenk-Braat et al. 2007) and what data was available was primarily for the time after virus delivery and not at the time of delivery. These questions should also be raised for plasmid based gene therapy. Long term follow-up data on patients who have received gene therapy may further ameliorate the safety concerns of this therapy. This will result in gene therapy being more readily applied to other nonmalignant conditions. The development of better plasmids and ways to integrate plasmids into the chromosome may lead to the greater use of plasmid rather than viral vectors for urological gene therapy.

MicroRNAs (MiRNA) are new targets for cancer therapy. These are small non-coding RNA molecules that bind to complementary sequences in the protein coding regions of mRNA and block their translation. Their expression levels vary in cancer and normal tissues (Catto et al. 2011). MiRNA-203 and MiRNA-221 have been shown to modulate the growth and apoptosis of human bladder cancer cell lines (Lu et al. 2010; Bo et al. 2011) and these could be new targets for therapy. Given the function of miRNA it is possible that these molecules could also be targets for non-cancer related bladder dysfunctions. This has not yet been explored and identifying such molecules may improve our knowledge of the development of these conditions.

\section{Conclusion}

The application of gene therapy for urological conditions is being evaluated in many preclinical disease models. In general the results obtained are encouraging and soon these therapies may move to Phase I trials.

\section{References}

Abrams, P., Cardozo, L., Fall, M., Griffiths, D., Rosier, P., Ulmsten, U., Van Kerrebroeck, P., Victor, A. and Wein, A. (2003) The standardisation of terminology in lower urinary tract function: report from the standardisation sub-committee of the International Continence Society. Urology 61, 37-49.

Akasaka, S., Suzuki, S., Shimizu, H., Igarashi, T., Akimoto, M. and Shimada, T. (2001) Suicide gene therapy for chemically induced rat bladder tumor entailing instillation of adenoviral vectors. Jpn J Cancer Res 92, 568-575.

Al-Dosari, M.S. and Gao, X. (2009) Nonviral gene delivery: principle, limitations, and recent progress. AAPS J11, 671-681.

Amit, D. and Hochberg, A. (2010) Development of targeted therapy for bladder cancer mediated by a double promoter plasmid expressing diphtheria toxin under the control of H19 and IGF2-P4 regulatory sequences. J Transl Med 8, 134.

Anderson, B. and Naish, W. (2008) Bladder cancer and smoking. Part 4: efficacy of health promotion. Br J Nurs 17, 1340-1344.

Andersson, K.E. and Wagner, G. (1995) Physiology of penile erection. Physiol Rev 75, 191236.

Apfel, S.C., Arezzo, J.C., Brownlee, M., Federoff, H. and Kessler, J.A. (1994) Nerve growth factor administration protects against experimental diabetic sensory neuropathy. Brain Res 634, 7-12.

Benedict, W.F., Tao, Z., Kim, C.S., Zhang, X., Zhou, J.H., Adam, L., McConkey, D.J., Papageorgiou, A., Munsell, M., Philopena, J., Engler, H., Demers, W., Maneval, 
D.C., Dinney, C.P. and Connor, R.J. (2004) Intravesical Ad-IFNalpha causes marked regression of human bladder cancer growing orthotopically in nude mice and overcomes resistance to IFN-alpha protein. Mol Ther 10, 525-532.

Bivalacqua, T.J. and Hellstrom, W.J. (2001) Potential application of gene therapy for the treatment of erectile dysfunction. J Androl 22, 183-190.

Bo, J., Yang, G., Huo, K., Jiang, H., Zhang, L., Liu, D. and Huang, Y. (2011) microRNA-203 suppresses bladder cancer development by repressing bcl-w expression. FEBS $J$ 278, 786-792.

Bonnet, M.E., Erbacher, P. and Bolcato-Bellemin, A.L. (2008) Systemic delivery of DNA or siRNA mediated by linear polyethylenimine (L-PEI) does not induce an inflammatory response. Pharm Res 25, 2972-2982.

Brown, J.S., Wessells, H., Chancellor, M.B., Howards, S.S., Stamm, W.E., Stapleton, A.E., Steers, W.D., Van Den Eeden, S.K. and McVary, K.T. (2005) Urologic complications of diabetes. Diabetes Care 28, 177-185.

Buscarini, M., Quek, M.L., Gilliam-Hegarich, S., Kasahara, N. and Bochner, B. (2007) Adenoviral receptor expression of normal bladder and transitional cell carcinoma of the bladder. Urol Int 78, 160-166.

Catto, J.W., Alcaraz, A., Bjartell, A.S., De Vere White, R., Evans, C.P., Fussel, S., Hamdy, F.C., Kallioniemi, O., Mengual, L., Schlomm, T. and Visakorpi, T. (2011) MicroRNA in Prostate, Bladder, and Kidney Cancer: A Systematic Review. Eur Urol.

Chancellor, M.B., Yoshimura, N., Pruchnic, R. and Huard, J. (2001) Gene therapy strategies for urological dysfunction. Trends Mol Med 7, 301-306.

Chen, L., Chen, D., Block, E., O'Donnell, M., Kufe, D.W. and Clinton, S.K. (1997) Eradication of murine bladder carcinoma by intratumor injection of a bicistronic adenoviral vector carrying cDNAs for the IL-12 heterodimer and its inhibition by the IL-12 p40 subunit homodimer. J Immunol 159, 351-359.

Chen, X., Kube, D.M., Cooper, M.J. and Davis, P.B. (2008) Cell surface nucleolin serves as receptor for DNA nanoparticles composed of pegylated polylysine and DNA. Mol Ther 16, 333-342.

Christ, G.J. (2011) Potential applications of gene therapy/transfer to the treatment of lower urinary tract diseases/disorders. Handb Exp Pharmacol, 255-265.

Christ, G.J., Day, N.S., Day, M., Santizo, C., Zhao, W., Sclafani, T., Zinman, J., Hsieh, K., Venkateswarlu, K., Valcic, M. and Melman, A. (2001) Bladder injection of "naked" hSlo/pcDNA3 ameliorates detrusor hyperactivity in obstructed rats in vivo. Am J Physiol Regul Integr Comp Physiol 281, R1699-1709.

Connor, R.J., Engler, H., Machemer, T., Philopena, J.M., Horn, M.T., Sutjipto, S., Maneval, D.C., Youngster, S., Chan, T.M., Bausch, J., McAuliffe, J.P., Hindsgaul, O. and Nagabhushan, T.L. (2001) Identification of polyamides that enhance adenovirusmediated gene expression in the urothelium. Gene Ther 8, 41-48.

Cooksley, C.D., Avritscher, E.B., Grossman, H.B., Sabichi, A.L., Dinney, C.P., Pettaway, C. and Elting, L.S. (2008) Clinical model of cost of bladder cancer in the elderly. Urology 71, 519-525.

Cozzi, P.J., Malhotra, S., McAuliffe, P., Kooby, D.A., Federoff, H.J., Huryk, B., Johnson, P., Scardino, P.T., Heston, W.D. and Fong, Y. (2001) Intravesical oncolytic viral therapy using attenuated, replication-competent herpes simplex viruses G207 and Nv1020 
is effective in the treatment of bladder cancer in an orthotopic syngeneic model. FASEB J 15, 1306-1308.

Darquet, A.M., Cameron, B., Wils, P., Scherman, D. and Crouzet, J. (1997) A new DNA vehicle for nonviral gene delivery: supercoiled minicircle. Gene Ther 4, 1341-1349.

Delo, D.M., Eberli, D., Williams, J.K., Andersson, K.E., Atala, A. and Soker, S. (2008) Angiogenic gene modification of skeletal muscle cells to compensate for ageinginduced decline in bioengineered functional muscle tissue. BJU Int 102, 878-884.

Den Otter, W., Dobrowolski, Z., Bugajski, A., Papla, B., Van Der Meijden, A.P., Koten, J.W., Boon, T.A., Siedlar, M. and Zembala, M. (1998) Intravesical interleukin-2 in T1 papillary bladder carcinoma: regression of marker lesion in 8 of 10 patients. J Urol 159, 1183-1186.

Dumey, N., Mongiat-Artus, P., Devauchelle, P., Lesourd, A., Cotard, J.P., Le Duc, A., Marty, M., Cussenot, O. and Cohen-Haguenauer, O. (2005) In vivo retroviral mediated gene transfer into bladder urothelium results in preferential transduction of tumoral cells. Eur Urol 47, 257-263.

Engler, H., Anderson, S.C., Machemer, T.R., Philopena, J.M., Connor, R.J., Wen, S.F. and Maneval, D.C. (1999) Ethanol improves adenovirus-mediated gene transfer and expression to the bladder epithelium of rodents. Urology 53, 1049-1053.

Fodor, I., Timiryasova, T., Denes, B., Yoshida, J., Ruckle, H. and Lilly, M. (2005) Vaccinia virus mediated p53 gene therapy for bladder cancer in an orthotopic murine model. J Urol 173, 604-609.

Freund, C.T., Tong, X.W., Block, A., Contant, C.F., Kieback, D.G., Rowley, D.R. and Lerner, S.P. (2000) Adenovirus-mediated suicide gene therapy for bladder cancer: comparison of the cytomegalovirus- and Rous sarcoma virus-promoter. Anticancer Res 20, 2811-2816.

Freund, C.T., Tong, X.W., Rowley, D., Engehausen, D., Frolov, A., Kieback, D.G. and Lerner, S.P. (2003) Combination of adenovirus-mediated thymidine kinase gene therapy with cytotoxic chemotherapy in bladder cancer in vitro. Urol Oncol 21, 197-205.

Gaetano, C., Catalano, A., Palumbo, R., Illi, B., Orlando, G., Ventoruzzo, G., Serino, F. and Capogrossi, M.C. (2000) Transcriptionally active drugs improve adenovirus vector performance in vitro and in vivo. Gene Ther 7, 1624-1630.

Gill, D.R., Pringle, I.A. and Hyde, S.C. (2009) Progress and prospects: the design and production of plasmid vectors. Gene Ther 16, 165-171.

Glazier, D.B., Bahnson, R.R., McLeod, D.G., von Roemeling, R.W., Messing, E.M. and Ernstoff, M.S. (1995) Intravesical recombinant tumor necrosis factor in the treatment of superficial bladder cancer: an Eastern Cooperative Oncology Group study. J Urol 154, 66-68.

Goins, W.F., Yoshimura, N., Phelan, M.W., Yokoyama, T., Fraser, M.O., Ozawa, H., Bennett, N.J., de Groat, W.C., Glorioso, J.C. and Chancellor, M.B. (2001) Herpes simplex virus mediated nerve growth factor expression in bladder and afferent neurons: potential treatment for diabetic bladder dysfunction. J Urol 165, 1748-1754.

Gomella, L.G., Mastrangelo, M.J., McCue, P.A., Maguire, H.J., Mulholland, S.G. and Lattime, E.C. (2001) Phase i study of intravesical vaccinia virus as a vector for gene therapy of bladder cancer. J Urol 166, 1291-1295.

Goss, J.R., Cascio, M., Goins, W.F., Huang, S., Krisky, D.M., Clarke, R.J., Johnson, J.W., Yokoyama, H., Yoshimura, N., Gold, M.S. and Glorioso, J.C. (2011) HSV Delivery of 
a Ligand-regulated Endogenous Ion Channel Gene to Sensory Neurons Results in Pain Control Following Channel Activation. Mol Ther 19, 500-506.

Hackett, P.B., Largaespada, D.A. and Cooper, L.J. (2010) A transposon and transposase system for human application. Mol Ther 18, 674-683.

Harimoto, K., Sugimura, K., Lee, C.R., Kuratsukuri, K. and Kishimoto, T. (1998) In vivo gene transfer methods in the bladder without viral vectors. Br J Urol 81, 870-874.

Harraz, A., Shindel, A.W. and Lue, T.F. (2010) Emerging gene and stem cell therapies for the treatment of erectile dysfunction. Nat Rev Urol 7, 143-152.

Haylen, B.T., de Ridder, D., Freeman, R.M., Swift, S.E., Berghmans, B., Lee, J., Monga, A., Petri, E., Rizk, D.E., Sand, P.K. and Schaer, G.N. (2010) An International Urogynecological Association (IUGA)/International Continence Society (ICS) joint report on the terminology for female pelvic floor dysfunction. Neurourol Urodyn 29, 4-20.

He, X.D., Wang, Z.P., Wei, H.Y., Zhou, Q., Wang, D.G., Tian, J.Q., Fu, S.J. and Rodriguez, R. (2009) Construction of urothelium-specific recombinant adenovirus and its inhibition in bladder cancer cell. Urol Int 82, 209-213.

Herr, H.W. and Morales, A. (2008) History of bacillus Calmette-Guerin and bladder cancer: an immunotherapy success story. J Urol 179, 53-56.

Horiguchi, Y., Larchian, W.A., Kaplinsky, R., Fair, W.R. and Heston, W.D. (2000) Intravesical liposome-mediated interleukin-2 gene therapy in orthotopic murine bladder cancer model. Gene Ther 7, 844-851.

Horinaga, M., Harsch, K.M., Fukuyama, R., Heston, W. and Larchian, W. (2005) Intravesical interleukin-12 gene therapy in an orthotopic bladder cancer model. Urology 66, 461466.

Inoue, K., Perrotte, P., Wood, C.G., Slaton, J.W., Sweeney, P. and Dinney, C.P. (2000) Gene therapy of human bladder cancer with adenovirus-mediated antisense basic fibroblast growth factor. Clin Cancer Res 6, 4422-4431.

Irie, A., Matsumoto, K., Anderegg, B., Kuruma, H., Kashani-Sabet, M., Scanlon, K.J., Uchida, T. and Baba, S. (2006) Growth inhibition efficacy of an adenovirus expressing dual therapeutic genes, wild-type p53, and anti-erbB2 ribozyme, against human bladder cancer cells. Cancer Gene Ther 13, 298-305.

Irwin, D.E., Kopp, Z.S., Agatep, B., Milsom, I. and Abrams, P. (2011) Worldwide prevalence estimates of lower urinary tract symptoms, overactive bladder, urinary incontinence and bladder outlet obstruction. BJU Int.

Jung, J.H., Kim, B.J., Chae, M.R., Kam, S.C., Jeon, J.H., So, I., Chung, K.H. and Lee, S.W. (2010) Gene transfer of TRPC6 (dominant negative) restores erectile function in diabetic rats. J Sex Med 7, 1126-1138.

Kamat, A.M. and Lamm, D.L. (2000) Intravesical therapy for bladder cancer. Urology 55, 161168.

Kasman, L.M., Barua, S., Lu, P., Rege, K. and Voelkel-Johnson, C. (2009) Polymer-enhanced adenoviral transduction of CAR-negative bladder cancer cells. Mol Pharm 6, $1612-$ 1619.

Kikkawa, K., Fujii, R., Kuramoto, T., Mori, T., Inagaki, T., Kohjimoto, Y., Iwahashi, M., Yamaue, H. and Hara, I. (2009) Dendritic cells with transduced survivin gene induce specific cytotoxic $\mathrm{T}$ lymphocytes in human urologic cancer cell lines. Urology 74, 222-228. 
Kuball, J., Wen, S.F., Leissner, J., Atkins, D., Meinhardt, P., Quijano, E., Engler, H., Hutchins, B., Maneval, D.C., Grace, M.J., Fritz, M.A., Storkel, S., Thuroff, J.W., Huber, C. and Schuler, M. (2002) Successful adenovirus-mediated wild-type p53 gene transfer in patients with bladder cancer by intravesical vector instillation. J Clin Oncol 20, 957965.

Lai, M.D., Chen, C.S., Yang, C.R., Yuan, S.Y., Tsai, J.J., Tu, C.F., Wang, C.C., Yen, M.C. and Lin, C.C. (2010) An HDAC inhibitor enhances the antitumor activity of a CMV promoter-driven DNA vaccine. Cancer Gene Ther 17, 203-211.

Lanson, N.A., Jr., Friedlander, P.L., Schwarzenberger, P., Kolls, J.K. and Wang, G. (2003) Replication of an adenoviral vector controlled by the human telomerase reverse transcriptase promoter causes tumor-selective tumor lysis. Cancer Res 63, 7936-7941.

Lawrencia, C., Mahendran, R. and Esuvaranathan, K. (2001) Transfection of urothelial cells using methyl-beta-cyclodextrin solubilized cholesterol and Dotap. Gene Ther 8, 760768.

Lee, S.S., Eisenlohr, L.C., McCue, P.A., Mastrangelo, M.J. and Lattime, E.C. (1994) Intravesical gene therapy: in vivo gene transfer using recombinant vaccinia virus vectors. Cancer Res 54, 3325-3328.

Lin, L.F., Zhu, G., Yoo, J.J., Soker, S., Sukhatme, V.P. and Atala, A. (2002) A system for the enhancement of adenovirus mediated gene transfer to uro-epithelium. J Urol 168, 813-818.

Loser, P., Jennings, G.S., Strauss, M. and Sandig, V. (1998) Reactivation of the previously silenced cytomegalovirus major immediate-early promoter in the mouse liver: involvement of NFkappaB. J Virol 72, 180-190.

Loskog, A.S., Fransson, M.E. and Totterman, T.T. (2005) AdCD40L gene therapy counteracts $\mathrm{T}$ regulatory cells and cures aggressive tumors in an orthotopic bladder cancer model. Clin Cancer Res 11, 8816-8821.

Lu, Q., Lu, C., Zhou, G.P., Zhang, W., Xiao, H. and Wang, X.R. (2010) MicroRNA-221 silencing predisposed human bladder cancer cells to undergo apoptosis induced by TRAIL. Urol Oncol 28, 635-641.

Malmstrom, P.U., Loskog, A.S., Lindqvist, C.A., Mangsbo, S.M., Fransson, M., Wanders, A., Gardmark, T. and Totterman, T.H. (2010) AdCD40L immunogene therapy for bladder carcinoma--the first phase I/IIa trial. Clin Cancer Res 16, 3279-3287.

McGarvey, T.W., Meng, R.D., Johnson, O., El-Deiry, W. and Malkowicz, S.B. (2001) Growth inhibitory effect of p21 and p53 containing adenoviruses on transitional cell carcinoma cell lines in vitro and in vivo. Urol Oncol 6, 155-162.

Melman, A., Bar-Chama, N., McCullough, A., Davies, K. and Christ, G. (2007) Plasmidbased gene transfer for treatment of erectile dysfunction and overactive bladder: results of a phase I trial. Isr Med Assoc J 9, 143-146.

Mitterberger, M., Marksteiner, R., Margreiter, E., Pinggera, G.M., Colleselli, D., Frauscher, F., Ulmer, H., Fussenegger, M., Bartsch, G. and Strasser, H. (2007) Autologous myoblasts and fibroblasts for female stress incontinence: a 1-year follow-up in 123 patients. BJU Int 100, 1081-1085.

Miyake, H., Hara, I., Hara, S., Arakawa, S. and Kamidono, S. (2000) Synergistic chemosensitization and inhibition of tumor growth and metastasis by adenovirusmediated P53 gene transfer in human bladder cancer model. Urology 56, 332-336. 
Miyazato, M., Sugaya, K., Goins, W.F., Wolfe, D., Goss, J.R., Chancellor, M.B., de Groat, W.C., Glorioso, J.C. and Yoshimura, N. (2009) Herpes simplex virus vectormediated gene delivery of glutamic acid decarboxylase reduces detrusor overactivity in spinal cord-injured rats. Gene Ther 16, 660-668.

Miyazato, M., Sugaya, K., Saito, S., Chancellor, M.B., Goins, W.F., Goss, J.R., de Groat, W.C., Glorioso, J.C. and Yoshimura, N. (2010) Suppression of detrusor-sphincter dyssynergia by herpes simplex virus vector mediated gene delivery of glutamic acid decarboxylase in spinal cord injured rats. J Urol 184, 1204-1210.

Muthana, M., Giannoudis, A., Scott, S.D., Fang, H.Y., Coffelt, S.B., Morrow, F.J., Murdoch, C., Burton, J., Cross, N., Burke, B., Mistry, R., Hamdy, F., Brown, N.J., Georgopoulos, L., Hoskin, P., Essand, M., Lewis, C.E. and Maitland, N.J. (2011) Use of Macrophages to Target Therapeutic Adenovirus to Human Prostate Tumors. Cancer Res 71, 1805-1815.

Nagabhushan, T.L., Maneval, D.C., Benedict, W.F., Wen, S.F., Ihnat, P.M., Engler, H. and Connor, R.J. (2007) Enhancement of intravesical delivery with Syn3 potentiates interferon-alpha2b gene therapy for superficial bladder cancer. Cytokine Growth Factor Rev 18, 389-394.

Ninalga, C., Loskog, A., Klevenfeldt, M., Essand, M. and Totterman, T.H. (2005) CpG oligonucleotide therapy cures subcutaneous and orthotopic tumors and evokes protective immunity in murine bladder cancer. J Immunother 28, 20-27.

Ogawa, R., Kagiya, G., Feril, L.B., Jr., Nakaya, N., Nozaki, T., Fuse, H. and Kondo, T. (2004) Ultrasound mediated intravesical transfection enhanced by treatment with lidocaine or heat. J Urol 172, 1469-1473.

Ohana, P., Bibi, O., Matouk, I., Levy, C., Birman, T., Ariel, I., Schneider, T., Ayesh, S., Giladi, H., Laster, M., de Groot, N. and Hochberg, A. (2002) Use of H19 regulatory sequences for targeted gene therapy in cancer. Int J Cancer 98, 645-650.

Olivares, E.C., Hollis, R.P., Chalberg, T.W., Meuse, L., Kay, M.A. and Calos, M.P. (2002) Sitespecific genomic integration produces therapeutic Factor IX levels in mice. Nat Biotechnol 20, 1124-1128.

Pagliaro, L.C., Keyhani, A., Williams, D., Woods, D., Liu, B., Perrotte, P., Slaton, J.W., Merritt, J.A., Grossman, H.B. and Dinney, C.P. (2003) Repeated intravesical instillations of an adenoviral vector in patients with locally advanced bladder cancer: a phase I study of p53 gene therapy. J Clin Oncol 21, 2247-2253.

Pan, J.G., Zhou, X., Zeng, G.W. and Han, R.F. (2011) Suppression of bladder cancer growth in mice by adeno-associated virus vector-mediated endostatin expression. Tumour Biol 32, 301-310.

Persu, C., Cauni, V., Gutue, S., Blaj, I., Jinga, V. and Geavlete, P. (2010) From interstitial cystitis to chronic pelvic pain. J Med Life 3, 167-174.

Pirollo, K.F., Rait, A., Zhou, Q., Zhang, X.Q., Zhou, J., Kim, C.S., Benedict, W.F. and Chang, E.H. (2008) Tumor-targeting nanocomplex delivery of novel tumor suppressor RB94 chemosensitizes bladder carcinoma cells in vitro and in vivo. Clin Cancer Res 14, 2190-2198.

Pong, R.C., Lai, Y.J., Chen, H., Okegawa, T., Frenkel, E., Sagalowsky, A. and Hsieh, J.T. (2003) Epigenetic regulation of coxsackie and adenovirus receptor (CAR) gene promoter in urogenital cancer cells. Cancer Res 63, 8680-8686. 
Qiu, X., Sun, C., Yu, W., Lin, H., Sun, Z., Chen, Y., Wang, R. and Dai, Y. (2011) Combined Strategy of Mesenchymal Stem Cells Injection with VEGF Gene Therapy for the Treatment of Diabetes Associated Erectile Dysfunction. J Androl.

Ramesh, N., Ge, Y., Ennist, D.L., Zhu, M., Mina, M., Ganesh, S., Reddy, P.S. and Yu, D.C. (2006) CG0070, a conditionally replicating granulocyte macrophage colonystimulating factor--armed oncolytic adenovirus for the treatment of bladder cancer. Clin Cancer Res 12, 305-313.

Ramesh, N., Memarzadeh, B., Ge, Y., Frey, D., VanRoey, M., Rojas, V. and Yu, D.C. (2004) Identification of pretreatment agents to enhance adenovirus infection of bladder epithelium. Mol Ther 10, 697-705.

Sachs, M.D., Ramamurthy, M., Poel, H., Wickham, T.J., Lamfers, M., Gerritsen, W., Chowdhury, W., Li, Y., Schoenberg, M.P. and Rodriguez, R. (2004) Histone deacetylase inhibitors upregulate expression of the coxsackie adenovirus receptor (CAR) preferentially in bladder cancer cells. Cancer Gene Ther 11, 477-486.

Saint, F., Kurth, N., Maille, P., Vordos, D., Hoznek, A., Soyeux, P., Patard, J.J., Abbou, C.C. and Chopin, D.K. (2003) Urinary IL-2 assay for monitoring intravesical bacillus Calmette-Guerin response of superficial bladder cancer during induction course and maintenance therapy. Int J Cancer 107, 434-440.

Sasaki, K., Chancellor, M.B., Goins, W.F., Phelan, M.W., Glorioso, J.C., de Groat, W.C. and Yoshimura, N. (2004) Gene therapy using replication-defective herpes simplex virus vectors expressing nerve growth factor in a rat model of diabetic cystopathy. Diabetes 53, 2723-2730.

Sasaki, K., Chancellor, M.B., Phelan, M.W., Yokoyama, T., Fraser, M.O., Seki, S., Kubo, K., Kumon, H., Groat, W.C. and Yoshimura, N. (2002) Diabetic cystopathy correlates with a long-term decrease in nerve growth factor levels in the bladder and lumbosacral dorsal root Ganglia. J Urol 168, 1259-1264.

Sazawa, A., Watanabe, T., Tanaka, M., Haga, K., Fujita, H., Harabayashi, T., Shinohara, N., Koyanagi, T. and Kuzumaki, N. (2002) Adenovirus mediated gelsolin gene therapy for orthotopic human bladder cancer in nude mice. J Urol 168, 1182-1187.

Schenk-Braat, E.A., van Mierlo, M.M., Wagemaker, G., Bangma, C.H. and Kaptein, L.C. (2007) An inventory of shedding data from clinical gene therapy trials. J Gene Med 9, 910-921.

Seth, S., Matsui, Y., Fosnaugh, K., Liu, Y., Vaish, N., Adami, R., Harvie, P., Johns, R., Severson, G., Brown, T., Takagi, A., Bell, S., Chen, Y., Chen, F., Zhu, T., Fam, R., Maciagiewicz, I., Kwang, E., McCutcheon, M., Farber, K., Charmley, P., Houston Jr, M.E., So, A., Templin, M.V. and Polisky, B. (2011) RNAi-based Therapeutics Targeting Survivin and PLK1 for Treatment of Bladder Cancer. Mol Ther.

Shiau, A.L., Lin, C.Y., Tzai, T.S. and Wu, C.L. (2001) Postoperative immuno-gene therapy of murine bladder tumor by in vivo administration of retroviruses expressing mouse interferon-gamma. Cancer Gene Ther 8, 73-81.

Shibata, M.A., Horiguchi, T., Morimoto, J. and Otsuki, Y. (2003) Massive apoptotic cell death in chemically induced rat urinary bladder carcinomas following in situ HSVtk electrogene transfer. J Gene Med 5, 219-231.

Shieh, G.S., Shiau, A.L., Yo, Y.T., Lin, P.R., Chang, C.C., Tzai, T.S. and Wu, C.L. (2006) Lowdose etoposide enhances telomerase-dependent adenovirus-mediated cytosine 
deaminase gene therapy through augmentation of adenoviral infection and transgene expression in a syngeneic bladder tumor model. Cancer Res 66, 9957-9966.

Shirakawa, T., Hamada, K., Zhang, Z., Okada, H., Tagawa, M., Kamidono, S., Kawabata, M. and Gotoh, A. (2004) A cox-2 promoter-based replication-selective adenoviral vector to target the cox-2-expressing human bladder cancer cells. Clin Cancer Res 10, $4342-4348$.

Shokeir, A.A., Harraz, A.M. and El-Din, A.B. (2010) Tissue engineering and stem cells: basic principles and applications in urology. Int J Urol 17, 964-973.

Sidi, A.A., Ohana, P., Benjamin, S., Shalev, M., Ransom, J.H., Lamm, D., Hochberg, A. and Leibovitch, I. (2008) Phase I/II marker lesion study of intravesical BC-819 DNA plasmid in $\mathrm{H} 19$ over expressing superficial bladder cancer refractory to bacillus Calmette-Guerin. J Urol 180, 2379-2383.

Siemens, D.R., Crist, S., Austin, J.C., Tartaglia, J. and Ratliff, T.L. (2003) Comparison of viral vectors: gene transfer efficiency and tissue specificity in a bladder cancer model. $J$ Urol 170, 979-984.

Stavropoulos, N.E., Hastazeris, K., Filiadis, I., Mihailidis, I., Ioachim, E., Liamis, Z. and Kalomiris, P. (2002) Intravesical instillations of interferon gamma in the prophylaxis of high risk superficial bladder cancer--results of a controlled prospective study. Scand J Urol Nephrol 36, 218-222.

Sutton, M.A., Berkman, S.A., Chen, S.H., Block, A., Dang, T.D., Kattan, M.W., Wheeler, T.M., Rowley, D.R., Woo, S.L. and Lerner, S.P. (1997) Adenovirus-mediated suicide gene therapy for experimental bladder cancer. Urology 49, 173-180.

Tanaka, A.S., Tanaka, M. and Komuro, K. (1998) A highly efficient method for the sitespecific integration of transfected plasmids into the genome of mammalian cells using purified retroviral integrase. Gene 216, 67-76.

Tanaka, M. and Grossman, H.B. (2003) In vivo gene therapy of human bladder cancer with PTEN suppresses tumor growth, downregulates phosphorylated Akt, and increases sensitivity to doxorubicin. Gene Ther 10, 1636-1642.

Tao, Z., Connor, R.J., Ashoori, F., Dinney, C.P., Munsell, M., Philopena, J.A. and Benedict, W.F. (2006) Efficacy of a single intravesical treatment with Ad-IFN/Syn 3 is dependent on dose and urine IFN concentration obtained: implications for clinical investigation. Cancer Gene Ther 13, 125-130.

Terao, S., Shirakawa, T., Kubo, S., Bishunu, A., Lee, S.J., Goda, K., Tsukuda, M., Hamada, K., Tagawa, M., Takenaka, A., Fujisawa, M. and Gotoh, A. (2007) Midkine promoterbased conditionally replicative adenovirus for targeting midkine-expressing human bladder cancer model. Urology 70, 1009-1013.

Thalmann, G.N., Dewald, B., Baggiolini, M. and Studer, U.E. (1997) Interleukin-8 expression in the urine after bacillus Calmette-Guerin therapy: a potential prognostic factor of tumor recurrence and progression. J Urol 158, 1340-1344.

Thalmann, G.N., Sermier, A., Rentsch, C., Mohrle, K., Cecchini, M.G. and Studer, U.E. (2000) Urinary Interleukin- 8 and 18 predict the response of superficial bladder cancer to intravesical therapy with bacillus Calmette-Guerin. J Urol 164, 2129-2133.

Thomas, C.E., Ehrhardt, A. and Kay, M.A. (2003) Progress and problems with the use of viral vectors for gene therapy. Nat Rev Genet 4, 346-358.

Tsai, Y.S., Shiau, A.L., Chen, Y.F., Tsai, H.T., Lee, H.L., Tzai, T.S. and Wu, C.L. (2009) Enhancement of antitumor immune response by targeted interleukin-12 
electrogene transfer through antiHER2 single-chain antibody in a murine bladder tumor model. Vaccine 27, 5383-5392.

Tsai, Y.S., Shiau, A.L., Chen, Y.F., Tsai, H.T., Tzai, T.S. and Wu, C.L. (2010) Enhancement of antitumor activity of gammaretrovirus carrying IL-12 gene through genetic modification of envelope targeting HER2 receptor: a promising strategy for bladder cancer therapy. Cancer Gene Ther 17, 37-48.

van der Poel, H.G., Molenaar, B., van Beusechem, V.W., Haisma, H.J., Rodriguez, R., Curiel, D.T. and Gerritsen, W.R. (2002) Epidermal growth factor receptor targeting of replication competent adenovirus enhances cytotoxicity in bladder cancer. J Urol 168, 266-272.

Wang, H., Satoh, M., Abe, H., Sunamura, M., Moriya, T., Ishidoya, S., Saito, S., Hamada, H. and Arai, Y. (2006) Oncolytic viral therapy by bladder instillation using an E1A, E1B double-restricted adenovirus in an orthotopic bladder cancer model. Urology 68, 674-681.

Wood, M., Perrotte, P., Onishi, E., Harper, M.E., Dinney, C., Pagliaro, L. and Wilson, D.R. (1999) Biodistribution of an adenoviral vector carrying the luciferase reporter gene following intravesical or intravenous administration to a mouse. Cancer Gene Ther 6, 367-372.

Wu, Q., Esuvaranathan, K. and Mahendran, R. (2004) Monitoring the response of orthotopic bladder tumors to granulocyte macrophage colony-stimulating factor therapy using the prostate-specific antigen gene as a reporter. Clin Cancer Res 10, 6977-6984.

Wu, Q., Mahendran, R. and Esuvaranathan, K. (2003) Nonviral cytokine gene therapy on an orthotopic bladder cancer model. Clin Cancer Res 9, 4522-4528.

Xu, H.J., Zhou, Y., Seigne, J., Perng, G.S., Mixon, M., Zhang, C., Li, J., Benedict, W.F. and Hu, S.X. (1996) Enhanced tumor suppressor gene therapy via replication-deficient adenovirus vectors expressing an N-terminal truncated retinoblastoma protein. Cancer Res 56, 2245-2249.

Yamashita, M., Rosser, C.J., Zhou, J.H., Zhang, X.Q., Connor, R.J., Engler, H., Maneval, D.C., Karashima, T., Czerniak, B.A., Dinney, C.P. and Benedict, W.F. (2002) Syn3 provides high levels of intravesical adenoviral-mediated gene transfer for gene therapy of genetically altered urothelium and superficial bladder cancer. Cancer Gene Ther 9, 687-691.

Yew, N.S., Zhao, H., Wu, I.H., Song, A., Tousignant, J.D., Przybylska, M. and Cheng, S.H. (2000) Reduced inflammatory response to plasmid DNA vectors by elimination and inhibition of immunostimulatory CpG motifs. Mol Ther 1, 255-262.

Yokoyama, H., Sasaki, K., Franks, M.E., Goins, W.F., Goss, J.R., de Groat, W.C., Glorioso, J.C., Chancellor, M.B. and Yoshimura, N. (2009) Gene therapy for bladder overactivity and nociception with herpes simplex virus vectors expressing preproenkephalin. Hum Gene Ther 20, 63-71.

Yoshimura, N., Kato, R., Chancellor, M.B., Nelson, J.B. and Glorioso, J.C. (2010) Gene therapy as future treatment of erectile dysfunction. Expert Opin Biol Ther 10, 13051314.

Zaharoff, D.A., Hoffman, B.S., Hooper, H.B., Benjamin, C.J., Jr., Khurana, K.K., Hance, K.W., Rogers, C.J., Pinto, P.A., Schlom, J. and Greiner, J.W. (2009) Intravesical immunotherapy of superficial bladder cancer with chitosan/interleukin-12. Cancer Res 69, 6192-6199. 
Zang, Z., Mahendran, R., Wu, Q., Yong, T. and Esuvaranathan, K. (2004) Non-viral tumor necrosis factor-alpha gene transfer decreases the incidence of orthotopic bladder tumors. Int J Mol Med 14, 713-717.

Zhang, J., Ramesh, N., Chen, Y., Li, Y., Dilley, J., Working, P. and Yu, D.C. (2002) Identification of human uroplakin II promoter and its use in the construction of CG8840, a urothelium-specific adenovirus variant that eliminates established bladder tumors in combination with docetaxel. Cancer Res 62, 3743-3750.

Zhang, X., Atala, A. and Godbey, W.T. (2008) Expression-targeted gene therapy for the treatment of transitional cell carcinoma. Cancer Gene Ther 15, 543-552.

Zhang, X. and Godbey, W.T. (2010) Preclinical evaluation of a gene therapy treatment for transitional cell carcinoma. Cancer Gene Ther.

Zhang, Z., Shirakawa, T., Hinata, N., Matsumoto, A., Fujisawa, M., Okada, H., Kamidono, S., Matsuo, M. and Gotoh, A. (2003) Combination with CD/5-FC gene therapy enhances killing of human bladder-cancer cells by radiation. J Gene Med 5, 860-867.

Zhu, Z., Xing, S., Lin, C., Zhang, X., Fu, M., Liang, X., Zeng, F., Lu, G. and Wu, M. (2003) Bladder cancer therapy using combined proliferating cell nuclear antigen antisense oligonucleotides and recombinant adenovirus p53. Chin Med J (Engl) 116, 1860-1863. 


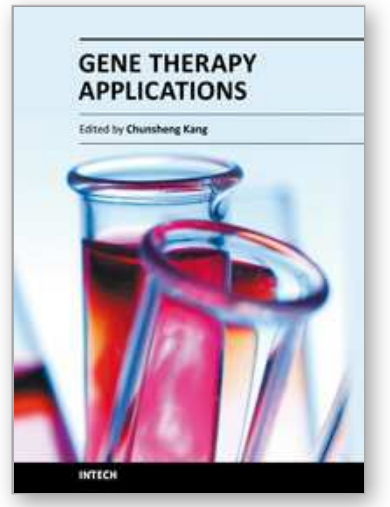

\author{
Gene Therapy Applications \\ Edited by Prof. Chunsheng Kang
}

ISBN 978-953-307-541-9

Hard cover, 492 pages

Publisher InTech

Published online 23, August, 2011

Published in print edition August, 2011

The aim of our book is to provide a detailed discussion of gene therapy application in human diseases. The book brings together major approaches: (1) Gene therapy in blood and vascular system, (2) Gene therapy in orthopedics, (3) Gene therapy in genitourinary system, (4) Gene therapy in other diseases. This source will make clinicians and researchers comfortable with the potential and problems of gene therapy application.

\title{
How to reference
}

In order to correctly reference this scholarly work, feel free to copy and paste the following:

Ratha Mahendran, Sin Mun Tham and Kesavan Esuvaranathan (2011). Gene Therapy in Urology, Gene Therapy Applications, Prof. Chunsheng Kang (Ed.), ISBN: 978-953-307-541-9, InTech, Available from: http://www.intechopen.com/books/gene-therapy-applications/gene-therapy-in-urology

\section{INTECH}

open science | open minds

\section{InTech Europe}

University Campus STeP Ri

Slavka Krautzeka 83/A

51000 Rijeka, Croatia

Phone: +385 (51) 770447

Fax: +385 (51) 686166

www.intechopen.com

\section{InTech China}

Unit 405, Office Block, Hotel Equatorial Shanghai

No.65, Yan An Road (West), Shanghai, 200040, China

中国上海市延安西路65号上海国际贵都大饭店办公楼405单元

Phone: +86-21-62489820

Fax: $+86-21-62489821$ 
(C) 2011 The Author(s). Licensee IntechOpen. This chapter is distributed under the terms of the Creative Commons Attribution-NonCommercialShareAlike-3.0 License, which permits use, distribution and reproduction for non-commercial purposes, provided the original is properly cited and derivative works building on this content are distributed under the same license. 